\title{
THE IMPORTANCE OF COMMITMENT TO THE YOUNG PEOPLE IN SERVICE TO THE FOUNDATION OF THE LOVE OF THE POOR, SURABAYA
}

\author{
Saefnat Saetban \\ Efrata Evangelical Theology College - Sidoarjo \\ E-mail:saefnat_sef@yahoo.co.id
}

\begin{abstract}
The phenomenon of the commitment of young people should be the object of attention for the church-the church or the Christian Foundations in developing their potential, As about the presence of young people the future of the church will be much better. Researchers have conducted preliminary observations and interviewed one of them. The information submitted is true that they have a longing to immerse themselves in the service to the maximum just haven't gained the trust of the management of the church.
\end{abstract}

Keywords: Church,Commitment, Christian Foundations, Young people.

\section{INTRODUCTION}

This, it should be recognized as absolute as it is to build the commitment of young people in the service, not an easy thing because of part of the church like the move of the church. They enjoy all of the facilities, events, and services of some of the churches. The motivation of the congregation who like to move the church is to pleasure yourself and look at the praise no more and a show, some just want to trytry, there are trying to find the church following his wishes, there are those who consider all of the church just the same, as a result, the church such as this tend not to be loyal to the church. The congregation feels saturated worship in the church because worship is only running as a routine that is done every Sunday, the church felt not get anything and the church. They regard the worship no more and the obligations and routines. The saturation of this, in the end, makes them leave the church. [1] In the Journal the author has previously argued that the Commitment should be understood as a responsibility. The idea of writing which is raised in this section, we want to formulate that commitment is a responsibility. This sense should be understood by young children at an age now, Because the system and the development of technology shows that young children have a great responsibility in 
all matters relating to the use of technology in the church, the foundation, and so on. This understanding is supported by the opinion of Max Jukes, The Importance Of Churches, He said that: We become a Christian to give an account of our lives to Christ, but we can only be a member of the family of God to give an account of our lives to other Christians. Because the church is God's family, we need to be members of the church locally.

The difference between "settlers" and "members" of the church can be seen from one word: COMMITMENT.[2] When a young man decided to believe in Christ at the same time given the responsibility Because he is considered as a member of the family of God. It is, not despite responsibility in the place of service. Therefore it has been accepted as a church in a local church, Howard W. Hunter, once said that: Characterizes the life of the congregation adults can be seen from its commitment to worship at a local church or a Foundation. A successful life, a good life, the life of the Christian righteous demands more than a contribution, even though every contribution is valuable. In the end, it requires a commitment that all my soul, which held firm, respected eternally against the principles that we know to be true in the commandments that God has given.[3] Associated with the opinion of this author pointed out that the success of young people the service is determined by the magnitude of the commitment he had.

Forms of commitment in explained in the collection further to wit: - Commitment to God ( obey the Lord, Ready to serve God for the rest of life) - a Commitment on the family - a Commitment at Church (faithfully in the local church, care of the growth of the church) - a Commitment on the job - Commitment in the Country.[4]

The action that is closest to commitment is loyalty. Loyal means being faithful and loyalty is defined as loyalty. In general, loyalty can be defined as loyalty to one against something or of certain services. Loyalty is something that arises in the absence of coercion but arises from a consciousness of its own. The first effort made to create customer satisfaction is more likely to affect the attitude of the customer, whereas the concept of customer loyalty is more emphasis on behavior rather than attitude. In fact, in the market, many customers are already satisfied with the product offered but may switch to other products on certain conditions, which is defined as satisfied but not loyal. loyalty is sincerity, not breaking a promise or a sense of betrayal, struggle, and grace, as well as maintaining love and keeping the promise together. So both of them can live filled with love, affection, respect, and sincerity in the 
heart, not hurt each other. loyalty means struggle, grace, sacrifice, and patience.

It can be seen from the fruit of the services in this section the authors underlying the observations of the Foundation of the Love of the Poor, Gunawan Setia Darma, has committed to conducting a holistic service to the church in the Foundation of the Love of the Poor, and the service is very evolved, with the addition of the soul. Because this foundation argues that the service holistic is one part of a believer who has a life that is committed.

Then the church should be able to see the needs of the community being served. It is taken seriously in any program services in the Foundation of the Love of the Poor. This service requires the commitment of every waiter who already decided to serve people who do not live in the adequacy of the economy, Fudation the Love of the Poor do social service. But this principle is not all people can accept actively, there is also passive in the servants holistic. The disciples were sent to do the mission just as Jesus has done, while in the service of Jesus, He did not only preach the Gospel but also pay attention to social issues.[4]

Difference concept about the meaning of mission as above bias carries practical implications for vocational (the concept of a job), local (concept about the kind of church service), and national (the concept of the involvement of the church in the community).

\section{RESEARCH METHOD}

In this paper, the researcher used a qualitative research method which is the discovery of theory from a growing phenomenon in the field of research. This is done In a professional manner in conducting the interviews with the research object and getting the data from the informants are accurate and can be trusted.[5] This principle is applied by research to be studied so as to produce a conclusion in a research. One of the authors namely Arikunto also provide affirmation that the Variable is object of research or what be the point of attention of a study.[6]

Type of qualitative research has two kinds of variables, namely: Variable predictions are used to predict changes in the variable one and the criteria, which change following changes in the variable prediction. Every time there is a change in the variable predictions than the variable criteria also must change. The opinion was delivered by Azwar, a correlation Study is a research that has a relationship between variables. Two or more variable is studied to see the relationships that occur between them without trying to change or hold the treatment of these variables.[7] 


\section{RESULTS AND DISCUSSION}

In general, scholars define organizational Commitment as an attitude to remain in the organization and engage in efforts to achieve the mission, values, and goals of the organization. This opinion is supported by Mathis and Jackson in Sopiah (2008, h.155) define organizational commitment as the degree to which employees believe in and accept the goals of the organization and will remain alive or will not leave the organization.[8] The goals of the organization should be diregenarasikan to young people, although still remain in the stage of controlling, senioriats in the church should be released in order to develop the church, for the church's future will be controlled by the young people. That is why they should be given.

In grammar may be different with the responsibility of young people in the service but have similarities in emphasizing the commitment.

Not only limited to this Due to Greenberg and Baron (1993), says that employees who have organizational commitment is the employee that is more stable and more productive so that in the end also more profitable for the organization.e responsibility to develop their potential.[9]

The main emphasis in this quote is the stability and productivity in the service, which should be recognized In an absolute sense that the second point is on young people as the successor generation. According to the author of the church or the Foundation of the Christian need to pay attention and develop the potential of young people as a strong bond for them, because if the church does not harness their potential then the world will use it. If up to this point is guaranteed For an absolute that the future of the church-the church or the Foundationreal estate Christians will culminate in failed. The church-the local church should have seen the development of the technology and capacity of young people each grazing.

Mowday, Porter, and Steers (1982) say that employees who commit to the organization will be more motivated to be present in the organization and strive to achieve the goals of the organization. Steers (1977) stated that organizational commitment is related to the intention to survive in the organization, but not directly related to the performance because performance is also related to motivation, clarity of role, and capability of employees. Steers and Porter in 1983.[10] Can explain the commitment that organizational commitment is a state where the individual becomes bound by his actions so it will rise to the belief that supports the activity and involvement. According to Robert and Kinicki (in Robert Kreitner, 2011) that 
organizational commitment is a reflection of where an employee is in recognizing the organization and being bound to its objectives. This is the attitude of work which is important because people have a commitment expected to show its availability to work harder in order to achieve the goals of the organization and have a greater desire to keep working in a company [11] Mowday (in Sopiah, 2008) calls work commitments as the other terms of organizational commitment. It also organizational commitment is the dimensions of an important behavior that can be used to assess the trend of employees, identify and involvement of someone who is relatively strong against the organization, and knowing the desire of members of the organization to maintain its membership in the organization and be willing to strive for the achievement of the goals of the organization and be able to accept the norms that exist within the company.[12]

\section{Affective Commitment}

Affective commitment, which is related to the desire to be bound to the organization. Individuals settled in the organization because of their desires. The key to this commitment is the want to. Commitment to be a basic strength for a person to do something positive impact on an organization. The desire to perform an act of course was born from a commitment. Affective commitment is defined as a state in affective or emotional reaction to the organization where the strength of the commitment of the individual is identified with the involvement of and the convenience of members of the organization. Effective Commitment is to helps researchers to find out the focused commitment of someone in the organization. Lead, workgroup, job, customer, job, and career. All of this requires effective and Commitment.[13]

\section{Continuance commitment}

The basis of continuance commitment is a commitment based on the needs of the rational. In other words, commitment is formed based on profit and loss, consider what must be sacrificed when will settle on an organization. The key to this commitment is the need to survive (and need to). Katner (in Sopiah, 2008) continuous Commitment (basis of continuance commitment), namely the commitment relating to the dedication of members in the continuing survival of the organization and generating the guy to make the sacrifice and invest in the organization.[14] 


\section{Normative Commitment}

Normative Commitment is the commitment that is based on norms that exist in the employees themselves, contain individual beliefs that will be the responsibility of the organization. He felt he had to endure because of loyalty. The key to this commitment is the obligation to endure in the organization (ought to). The authors conducted a meta-analysis to assess (a) relations among affective, continuance, and normative commitment to the organization and (b) the relationship between the three. forms of commitment and variables identified as antecedents, correlates, and consequences in the Three-Component Model of Meyer and Allen. They find all three forms of commitment are related yet distinguishable from one another as well as from job satisfaction, job involvement, and work commitments. Affective and continuance commitment generally correlated as expected with variable antecedents are hypothesized; there is no antecedent unique commitment normative identified. Also, as expected, all three forms of commitment related negatively to withdrawal cognition and turnover, and affective commitment correlates with the strongest and most beneficial with which relevant to the organization (attendance, performance, and behavior of citizens of the organization) and relevant to the employee (stress and conflict work-family) results. Commitment normative is also associated with the desired results, although not as strong as it is. Commitment to the continuation of unrelated, or related negatively, to these results. Comparisons of studies conducted within and outside North America revealed similarities but suggested that more systematic primary research concerning cultural differences.[15]

\section{The Significance Of The Research}

Research about the Importance of Commitment To the Young People in Service to The Foundation of the Love of the Poor. Often overlooked, however on the one hand young people in the church are considered as the successor generation. They are the people who could potentially even have the technological capability that can support the service in the church. The problem is the church does not involve the young to the maximum is not even given the responsibility of service. 


\section{CONCLUSION}

Based on the results of observation to the informant in the field in particular young people as the object of this study. The information widespread of young people. The foundation has not been paying attention to the lives of young people in total, so there are still some who have not been involved in any field, even did not take part in any religious activities.

Because they felt they needed in service, low self-esteem has no potential qualified, not equipped with understandingunderstanding the Word of God, do not get teaching about the challenges of life young, director of young people is not effective, a lot of young people who do not have this touch of love from home.

Concerning this information, then the Information needs to be known by the Foundation of the Love of the Poor Surabaya:

The first: the commitment of the youngmudia is the best opportunity to develop themselves competent in serving on the Foundation of the Love of the Poor Surabaya

The Second: the Commitment of young people is a serious struggle Because it is not affordable overall.

The third: the Commitment of young people need to be taught in the Foundation of Love People People Because many among them are the difficulty of the work, because working without the committed

Fourth: the Commitment of young people is Important Because many of whom who have difficulty in economic terms. That resulted in many young people, the wild and not active in the service of the Foundation of the Love of the Poor.

Fifth: the Commitment of young people is important Because the development of technology has attracted the attention of them, so most of them were not interested in spiritual activities in the Foundation of the Love of the Poor Surabaya

Sixth: the Commitment of young sting important because of the challenges of the times has been mengkaburkan the fighting spirit of them, so that they had experienced despair with the life that was lived in service to the Foundation of Love People People of Surabaya. 


\section{REFERENCES}

[1]. Lewis, Journal Of Building Commitment Hide Jalaat In The Church.Law, 2011.

[2]. Max Jukes, The Importance Of The Church-The Church, (New York, 2015)

[3]. Howard W. Hunter, The Teachings Of Pembimpin Church, 2018

[4]. Jonathan Edward, The Total Commitment (Solo: Yayasan Lembaga Sabda, 2012)

[5]. Sugiyono, Research Methods kuantitaf, Qualitative, and $R \& D$, (Bandung, Alfabeta, 2017),

[6]. Saifuddin Azwar,Research Methods (TK: tp, tt)

[7]. Sugiyono, Quantitative Research Methods and R \& D., (Bandung: ALFABETA, 2017)

[8]. Sopiah. . Resikaku Organizational, CV. And I Offset, Yogyakarta. Two thousand eighteen

[9]. Greenberg, J., \& Baron, R. A. behavior in organizations: understanding and managing the human side of work (ed 5.), Upstream Of The River, A Prentice. (1993). [10] Mowday, R. T., Porter, L. W., \& Steers, R. M. employee-organization linkages: the psychology of commitment, absenteisme, and turnover. Academic Media. (1982)

[11]. R. M. Steers, the Effectiveness of the Organization (berhemahan). Erlangga.
1983.

[12]. Kreitner, Robert and Angelo Kinicki. Organizational Behavior. Salamba Four. 2011)

[13]. Bauer, D. J., \& Curran, P. J. (2004). Integration with a variable models latent continuous and discrete: potential problems and promising opportunities. Psychological Methods.

[14]. Allen, N. J., Meyer, J. P. A three component Conceptualization of organizational commitment. Human Resource Management. (1990)

[15]. John P. Meyer, Affective, basis of continuance, and the commitment of the normal to the organization: the analysis of the Meta to its predecessor, the correlation, and the consequences, 2002. 